https://helda.helsinki.fi

\title{
Local Government in Uzbekistan
}

\section{Urinboyev, Rustam}

Springer

2018-09-23

Urinboyev , R 2018 , Local Government in Uzbekistan . in A Farazmand (ed.) , Global

Encyclopedia of Public Administration, Public Policy, and Governance . Springer . https://doi.org/10.1007/978-3-319

http://hdl.handle.net/10138/298403

https://doi.org/10.1007/978-3-319-31816-5_3665-1

draft

Downloaded from Helda, University of Helsinki institutional repository.

This is an electronic reprint of the original article.

This reprint may differ from the original in pagination and typographic detail.

Please cite the original version. 


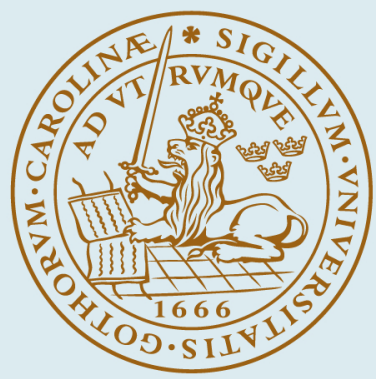

\title{
LUND UNIVERSITY
}

\section{Local Government in Uzbekistan}

\author{
Urinboyev, Rustam
}

Published in:

Global Encyclopedia of Public Administration, Public Policy, and Governance

Accepted/In press: 2018-01-10

\section{Document Version}

Version created as part of publication process; publisher's layout; not normally made publicly available

Link to publication

Citation for published version (APA):

Urinboyev, R. (2018). Local Government in Uzbekistan. In A. Farazmand (Ed.), Global Encyclopedia of Public Administration, Public Policy, and Governance Springer.

\section{General rights}

Copyright and moral rights for the publications made accessible in the public portal are retained by the authors and/or other copyright owners and it is a condition of accessing publications that users recognise and abide by the legal requirements associated with these rights.

- Users may download and print one copy of any publication from the public portal for the purpose of private study or research.

- You may not further distribute the material or use it for any profit-making activity or commercial gain

- You may freely distribute the URL identifying the publication in the public portal 


\section{Metadata of the chapter that will be visualized online}

\begin{tabular}{lll}
\hline Chapter Title & Local Government in Uzbekistan & \\
\hline Copyright Year & 2018 & \\
\hline Copyright Holder & Springer Nature Switzerland AG & \\
\hline Corresponding Author & Family Name & Urinboyev \\
& Particle & \\
Given Name & Rustamjon \\
& Suffix & \\
Organization/University & University of Helsinki, Aleksanteri \\
& City & Institute \\
& Country & Helsinki \\
& Division/Department & Finland \\
& Department of Sociology of Law, \\
& Organization/University & Faculty of Social Sciences \\
& City & Lund University \\
& Country & Sweden \\
& Email & rustamjon.urinboyev@soclaw.lu.se \\
\hline
\end{tabular}




\section{Local Government in}

3 Uzbekistan

4 Rustamjon Urinboyev

5 University of Helsinki,

6 Aleksanteri Institute, Helsinki, Finland

7 Department of Sociology of Law,

8 Faculty of Social Sciences,

AU1 9 Lund University, Lund, Sweden

\section{Synonyms}

Decentralization in Uzbekistan; Local government in Central Asia; Public administration in Uzbekistan; Subnational government in Uzbekistan

\section{Introduction}

Uzbekistan became an independent state in 1991 following the demise of the Soviet Union. Coming on the heels of a global discourse on good governance and decentralization, Uzbekistan embarked on the highly complex task of reforming its public administration system. The implementation of these reforms, however, proved to be a daunting task, since the country had to deal with its Soviet legacy and its internal power structures and contradictions: weak state institutions, poorly developed national identities, and entrenched subnational political networks (cf., 27 Ilkhamov 2004; Markowitz 2008; Melvin 2004). 28

Local government is one of the most problem- 29 atic areas in Uzbekistan where the failure of the 30 reform initiatives is quite evident. This chapter 31 delineates the processes involved and explores 32 the context, problems, quality, and trajectories of 33 local governance in Uzbekistan. More specifi- 34 cally, it addresses the following two questions: 35 (a) What are the responsibilities of local govern- 36 ments and do they carry them out in an adequate 37 and efficient manner? (b) How do local govern- 38 ments involve communities and their organiza- 39 tions in the governing process in terms of the 40 principles of good governance, such as transpar- 41 ency, accountability, rule of law, voice, democ- 42 racy, and accountability? In doing so, the paper 43 examines four conditions: contextual, structural, 44 institutional, and human resource. These condi- 45 tions are considered to be factors that can account 46 for the capacity of local governments in 47 Uzbekistan.

The rest of the chapter proceeds as follows: the 49 next section describes the internal structure of 50 local governments, which will be instructive in 51 understanding the conditions under which they 52 function in Uzbekistan. This is followed by the 53 presentation of a brief overview of the tasks 54 and service delivery responsibilities of local gov- 55 ernments. The financial conditions and actual ser- 56 vice delivery capacity of local governments are 57 then discussed. The section after that examines 58 the relations between the central and local 59 
government, followed by concluding remarks on the main trends and challenges local governments face. Suggestions on areas for governance reform are also provided.

\section{The Internal Structure of Local Governments}

In Uzbekistan, the local government consists of a local state administration (administrative body) and an elected local council (legislative body) at the regional (oblast) and district (raion) levels. Representatives are appointed/elected for a period of 5 years. The local administration represents the executive and regulatory bodies of the state at the regional, district, or city/town levels and implements the policies of the president and central government in the provinces. All the heads of the local state administrations are appointed by the central government, subject to [symbolical] approval by the corresponding local councils (Bektemirov and Rahimov 2001). The president appoints regional (oblast level) governors, who in turn appoint district and city/town governors that come under regional subordination. Thus, the district and city governors are accountable to the regional governor, who in turn is accountable to the president. This means that local governors often experience double or even triple subordination, being accountable to the regional governor, the central government, and the president.

The local councils, running alongside the local state administrations, are the primary local legislative bodies. The council representatives are elected by the residents of the respective administrative-territorial units through general and direct vote (Bektemirov and Rahimov 2001). As elected bodies, the local councils are expected to express and realize the will of the citizens in their respective administrativeterritorial units. At least in theory, local councils can exert some influence over their administrative bodies. However, this is not the case in practice as the heads of the local state administrations enjoy absolute power in the management of local affairs (e.g., Popa and Munteanu 2001). Since all the governors are appointed, the local councils cannot exert significant influence on them. Even 105 though governors periodically report to their 106 local councils on the current situation of the terri- 107 tory, this process is mainly symbolic in nature 108 (Bektemirov and Rahimov 2001). This is because 109 the governors of the regional, city, or district state 110 administrations simultaneously exercise execu- 111 tive authority and serve as local council chairmen. 112 This means it is very difficult to distinguish 113 between the functions of the local state adminis- 114 tration and the local self-government bodies, since 115 the same individual (i.e., the governor) heads both 116 branches of power.

In addition to the regional and district 118 state administrations, there are sub-district level 119 governance institutions - mahalla committees - in 120 towns and rural areas. Mahalla committees 121 were part of the state farms, collective farms, 122 and enterprises during the Soviet era, but 123 shortly after independence, Uzbek authorities 124 revamped these institutions, assigning them 125 new legal status as "local self-government 126 bodies of citizens" (Giffen et al. 2005). Mahalla 127 committees assist district/town administrations 128 in implementing local development projects, 129 collecting taxes, administering social welfare pro- 130 grams, maintaining and repairing roads, disposing 131 of waste, ensuring security and order, removing 132 garbage, maintaining playgrounds and sports 133 fields, and many other tasks that are of local 134 importance (Bektemirov and Rahimov 2001; 135 Urinboyev 2011). Regarding the financing and 136 autonomy of these sub-district self-government 137 institutions vis-a-vis the higher-level local state 138 administrations, they are fully dependent on 139 budget allocations from the latter and regularly 140 report to the head of the district or city/town 141 administrations. The chairmen and secretaries 142 of the mahalla committees are salaried state offi- 143 cials. This means that mahalla committees do not 144 have any real capacity to act as sites of local 145 democracy and participation but merely serve 146 as sub-district extensions of the local state 147 administrations.

However, it should be noted that some form 149 of informal autonomy can be observed at the 150 level of the informal/social mahalla. Hence, 151 there is a need to distinguish between the mahalla 152 
committees (administrative mahalla) and the informal mahallas (social mahalla). The Uzbek people usually refer to the chairmen of the mahalla committees as the "eyes and ears of the local government" ("quloq" in the Uzbek language), given the fact that they serve the interests of the local government. The leaders of the social mahallas, on the other hand, are elected by mahalla residents during informal gatherings in mosques or teahouses (guzar). They work pro bono for the community and represent the interests of the mahalla people. The social mahallas function informally and autonomously and can thus be regarded as a genuine citizen selfgovernment institution (Urinboyev 2014, 2018). They offer a community-based alternative dispute resolution mechanism and provide a space for informal governance of everyday life and social relations. The analysis of scholarly literature shows that for many Uzbeks, social mahallas are more legitimate and easily accessible than the formal state institutions (Aminova and Jegers 2011; Masaru 2006; Sievers 2002; Urinboyev 2011, 2013a, b).

\section{Tasks and Service Delivery Responsibilities of Local Governments}

The tasks decentralized to local governments in Uzbekistan include environmental protection, prevention of natural and technological accidents, fire protection, public sanitation, public order and security, local economic and social development, culture, tourism, sports, maintenance of leisure facilities, communal services (e.g., water, gas, electricity, heat, waste management, sewage, engineering infrastructures), construction, maintenance and local road repair, public transport, employment and job creation support, and the development of small and medium enterprises.

Almost all healthcare services are provided by the public authorities. The central government manages healthcare services through the regional, district, and city/town level healthcare offices of the Ministry of Health. Healthcare services are primarily financed by the central budget and administered by territorial structures of the respective ministry. The local government is 198 only responsible for the maintenance and renova- 199 tion of healthcare institutions (Bektemirov and 200 Rahimov 2001). Schooling is the joint responsi- 201 bility of the central and local government in the 202 sense that the local offices of the Ministry of 203 Education pay teachers' wages and oversee 204 administrative control; other expenditures such 205 as school maintenance are included in the local 206 government budget (Bektemirov and Rahimov 207 2001).

Unlike Kazakhstan, Kyrgyzstan, and 209 Tajikistan where local governments are responsi- 210 ble mainly for providing social assistance to 211 needy families, the mahalla committees 212 (administrative mahalla) in Uzbekistan are 213 responsible for the administration and targeting 214 of state social welfare benefits, such as child 215 and maternity benefits, and social assistance to 216 low-income families, families with children 217 under 16, and single mothers with children under 218 2 (Coudouel and Marnie 1999; Micklewright and 219 Marnie 2005). Funding for these programs is 220 established centrally as part of the consolidated 221 budget expenditures, which in turn are transferred 222 to the mahalla committees. The remaining social 223 protection programs (e.g., pensions, veterans of 224 the war benefits) are the responsibility of the dis- 225 trict/city level units of the Ministry of Labor and 226 Social Protection (Bektemirov and Rahimov 227 2001).

\section{Financial Conditions and Actual Service 229 Delivery Capacity of Local Governments 230}

One of the most important criteria used by the 231 citizens to assess the performance of local 232 governments is the quality and accessibility of 233 local public services (Popa and Munteanu 2001). 234 However, there are only a few studies with data on 235 citizens' satisfaction with local government 236 performance in Uzbekistan. This is because 237 Uzbekistan has long been a heavily authoritarian 238 and closed country, making it difficult for local 239 and foreign organizations and researchers to eval- 240 uate the performance and effectiveness of the 241 local government in the country. Neema Noori's 242 
(2006) study of decentralization processes in Uzbekistan is one of the few in this respect. As Noori argues, decentralization has had a negative impact on public service delivery in Uzbekistan because it was not accompanied by the corresponding resources and consequently worsened the quality and accessibility of public services. Hence, the central government has delegated numerous tasks and service delivery responsibilities to the local governments without providing adequate funding (Kandiyoti 2007; Noori 2006). One of the key challenges to improve the performance of local governments in Uzbekistan is to bridge the gap between their economic and social functions and the meagre financial means available for their implementation.

The healthcare provision situation is also problematic. In Uzbekistan, the healthcare system is financed by the state, which means medical services should be free of charge. However, the healthcare system is de facto private and highly reliant on informal forms of financing. Most patients have to make informal payments to medical professionals in order to receive proper medical treatment, even though the public authorities claim that citizens are entitled to free medical care. Local governments do not have sufficient resources to maintain adequately the healthcare infrastructures, the majority of which were built during the Soviet period.

A similar situation can also be observed in the field of education. Due to their vulnerable financial situation, local governments do not have sufficient resources to maintain local schools and provide an adequate number of books or to build modern sports facilities. The parents usually cover these expenditures.

These problems can be largely explained by the fact that the local governments in Uzbekistan have limited financial autonomy and are strongly dependent on the central government (Ergashev et al. 2006; Sievers 2002; Urinboyev 2015). Local budgets mainly consist of transfers from the central government and local tax revenues. Local budget planning is centralized and closely tied to the national budget. This implies that central government bodies determined the revenue bases of the local budgets. The local governments cannot 291 independently establish tax rates or collect their 292 own revenues through local taxes, with the excep- 293 tion of some insignificant local fees, taxes, and 294 duties, such as a land tax. National budget funds 295 are redistributed among different regions by 296 deducting budget surpluses from the regions that 297 perform well and making allocations in the form 298 of subventions, subsidies, or equalization trans- 299 fers to vulnerable regions that cannot cover their 300 needs. The revenues collected from local taxes 301 constitute a small portion of the local govern- 302 ments' revenues and are insufficient for covering 303 even the basic expenses. Hence, the ability of 304 local governments to raise their own revenues is 305 considerably limited, and they remain dependent 306 on transfers from the central government to fulfill 307 their service delivery functions. Consequently, 308 they neither enjoy fiscal autonomy nor do they 309 receive transfers from the central government that 310 are sufficient to meet their service delivery needs 311 (Leschenko and Troschke 2006). 312

Due to the incapacity of the local government 313 to address adequately the local needs, social 314 mahallas have evolved to respond to the declining 315 state capacity in the post-Soviet era, acting as a 316 pseudo-local government entity. This means that 317 people living in the same neighborhood (mahalla) 318 pool their efforts and engage in mutual aid prac- 319 tices by exchanging labor, money, material goods, 320 and services. Typical mutual aid practices include 321 the community financing of constructing irriga- 322 tion facilities, cleaning streets, asphalting roads, 323 building houses or mosques, organizing wed- 324 dings, funerals and circumcision feasts, and 325 many other services not provided by the local 326 government.

\section{The Relations Between the Central and Local Government}

The local government in Uzbekistan functions in a 330 rather complex environment characterized by an 331 authoritarian political culture, limited financial 332 autonomy, and weak local legislative bodies. 333 The power and functions between the central 334 state agencies and local governments are 335 
ambiguously distributed, which largely derives from the deficiencies in national laws that do not clearly specify the functions and powers across various tiers of the government. The central government bodies make most of the administrative decisions concerning district and regional public service delivery issues. In these bodies, a hierarchy of power starts at the ministry, followed by the ministry's main regional departments, and followed by the district or city units. Ministries control the daily activities of their territorial agencies and directly appoint their heads, in coordination with the governor, which implies that the territorial units of the ministries are accountable to their central bodies and thereby rarely coordinate with local governments.

Local councils, despite having official status as local legislative bodies, are in practice subordinated to the local state administrations. Hence, institutions of self-governance fulfill completely different functions and aims than the officially declared ones. This means that there is very little or no understanding of the true essence of local government reform in the country. As Abdukhalilov (2007) notes, in Uzbekistan, administrative reforms are often understood as a cutback in staff or an attempt to save money. More importantly, administrative reforms do not contain a single paragraph about the necessity to change the hierarchical norms and mentality of the managers.

Accordingly, Uzbekistan's public administration system can hardly be regarded as "decentralized" given that local governments are highly dependent on the central government at all levels - administratively, financially, and politically. Overdependence on the central government limits the ability of local governments to support local development. The malfunctioning local governments are mainly the outcome of a centralized government that does not delegate any real autonomy to local administrations (Bektemirov and Rahimov 2001). Under these circumstances political and civil servants at all levels do not feel any accountability to the citizens; rather, they try to meet the expectations of those who have the power and authority to hire them. Public participation in local politics is almost nonexistent, and local elections are merely used to assert and legit- 384 imize the central government's influence in the 385 periphery. Openness and transparency are not 386 viewed as a norm in the day-to-day operations of 387 the local administrations. Local government offi- 388 cials care less about informing people about their 389 work or listening to their opinions on the level and 390 quality of public services. They are chiefly 391 concerned with fulfilling the orders and expecta- 392 tions of the central government.

\section{Concluding Remarks}

As shown in the previous sections, the relation- 395 ship between the local state administrations and 396 the central government is often based on subordi- 397 nate relations rather than on mutual cooperation. 398 Local government reform is interpreted merely 399 in terms of citizens' active participation in local 400 government, but other key conditions for local 401 self-government (i.e., autonomy of local self- 402 government structures from the state) are largely 403 neglected (Ilkhamov 2004; Urinboyev 2015). As 404 the results demonstrate, the core challenge hinder- 405 ing local government reform in Uzbekistan comes 406 from the persistence of authoritarian style admin- 407 istrative practices. Although there have been some 408 local government reform initiatives in the country, 409 they remain "on paper" and have little or no effect 410 on the governance processes. In practice, the local 411 governments continue to be subordinated to the 412 central government in all public policy issues, be 413 it education, taxation, health care, welfare, or 414 agriculture. As a result, the local governments do 415 not have any real capacity to adequately address 416 the needs and concerns of citizens, as they are 417 merely concerned with implementing centrally 418 designed policies.

Another area of concern is financial autonomy. 420 Since the local governments do not have a solid 421 financial base and the important public policy 422 decisions are made at the central government 423 level, there is little or no possibility at the local 424 level for citizens to voice their concerns about 425 public goods and services. One visible conse- 426 quence is the emergence of citizens' alternatives: 427 informal coping strategies that are based on 428 
mutual aid practices. These alternative strategies are short-term solutions that have little to do with local development issues and negatively influence the image and legitimacy of the central government. It is thus suggested that local government reform should go beyond official proclamations and rhetoric and grant more political and financial autonomy in practice.

\section{Cross-References}

- Civil Service Development in Kazakhstan

- Governance in Tajikistan

> Local Government in Kazakhstan

- Local Government in Uzbekistan

P Public Administration in Kyrgyzstan

- Public Sector Reforms in Central Asia

\section{References}

Abdukhalilov A (2007) Stages and special features of the Administrative Reforms in the Republic of Uzbekistan. Cent Asia Caucasus 6(48):18. Retrieved from http:// cyberleninka.ru/article/n/stages-and-special-featuresof-the-administrative-reforms-in-the-republic-ofuzbekistan

Aminova M, Jegers M (2011) Informal structures and governance processes in transition economies: The Case of Uzbekistan. Int J Public Adm 34(9):579-590. https://doi.org/10.1080/01900692.2011.588436

Bektemirov K, Rahimov E (2001) Local Government in Uzbekistan. In: Popa V, Munteanu I (eds) Developing new rules in the old environment. Local governments in Eastern Europe, in the Caucasus and in Central Asia. Local Government and Public Service Reform Initiative, Open Society Institute Europe, Budapest, pp 469-520

Coudouel A, Marnie S (1999) From universal to targeted social assistance: an assessment of the Uzbek Experience. MOCT-MOST: Econ Policy Trans Econ 9(4):443-458

Ergashev B, Iusupov I, Pogrebniak A, Korenev I, Allaev B, Gaibullaev O, ..., Saifulin R (2006) Public Administration Reform in Uzbekistan. Probl Econ Transit 48(12):32-82

Giffen J, Earle L, Buxton C (2005) The development of civil society in Central Asia. Intrac Oxford. Retrieved from $\mathrm{http}: / /$ scholar.google.co.uk/scholar_url?url=http $\% 3 \mathrm{~A} \% 2 \mathrm{~F} \% 2 \mathrm{Fr} 4$ d.dfid.gov.uk $\% 2 \mathrm{FPDF} \% 2 \mathrm{FOutputs} \%$ 2FUrbanisation\%2FR7649-report.pdf\&hl=en\&sa= $\mathrm{T} \&$ oi $=$ ggp \&ct $=$ res\&cd $=332 \&$ ei $=$ NLbcVMi4NtLQqQHDmoCQBw\&scisig=
AAGBfm1XpZZJHWjfT4OyrmnbyP7hdALOiA\& 477 nossl $=1 \& w s=1279 \times 817 \quad 478$

Ilkhamov A (2004) the limits of centralization: regional 479 challenges in Uzbekistan. In: The transformation 480 of central asia. States and societies from soviet rule 481 to independence. Cornell University Press, Ithaca, 482 pp 159-181 483

Kandiyoti D (2007) Post-soviet institutional design and the 484 paradoxes of the Uzbek Path. Cent Asian Surv 485 26(1):31-48

486

Leschenko N, Troschke M (2006) Fiscal decentralization 487 in centralized states: the case of Central Asia (No. 261). 488 Arbeiten aus dem Osteuropa-Institut München. 489 Retrieved from http://www.econstor.eu/handle/10419/ 490 32273

Markowitz LP (2008) Local Elites, Prokurators and 492 Extraction in Rural Uzbekistan. Cent Asian Surv 493 27(1):1-14

Masaru S (2006) The politics of civil society, Mahalla and 495 NGOs: Uzbekistan. In: Osamu L, Tomohiko U (eds) 496 Reconstruction and interaction of Slavic Eurasia 497 and its neighbouring worlds. Slavic Research Center, 498 Hokkaido University, Sapporo, pp 335-370 499 Melvin NJ (2004) Authoritarian pathways in Central 500 Asia: a comparison of Kazakhstan, the Kyrgyz Repub- 501 lic, and Uzbekistan. In: Democracy and pluralism in 502 Central Eurasia, Cummings center series. Frank Cass, 503 London, pp 127-128 504

Micklewright J, Marnie S (2005) Targeting social assis- 505 tance in a transition economy: The Mahallas in Uzbek- 506 istan. Soc Policy Adm 39(4):431-447 507

Noori N (2006) Expanding state authority, cutting back 508 local services: decentralization and its contradictions 509 in Uzbekistan. Cent Asian Surv 25(4):533-549 510

Popa V, Munteanu I (2001) Local Government Reforms in 511 the Former Soviet Union: between hope and change. 512 In: Popa V, Munteanu I (eds) Developing new rules in 513 the old environment. Local governments in Eastern 514 Europe, in the Caucasus and in Central Asia. Local 515 Government and Public Service Reform Initiative, 516 Open Society Institute Europe, Budapest, pp 19-44. 517 Retrieved from http://unpan1.un.org/intradoc/groups/ 518 public/documents/APCITY/UNPAN008028.pdf 519

Sievers EW (2002) Uzbekistan's Mahalla: from Soviet to 520 Absolutist Residential Community Associations. J Int 521 Comp Law Chicago-Kent 2:91-158 522

Urinboyev R (2011) Law, social norms and welfare 523 as means of public administration: Case study 524 of Mahalla institutions in Uzbekistan. NISPAcee 525 J Public Adm Policy 4(1):33-57 526

Urinboyev R (2013a) Living law and political stability 527 in post-Soviet Central Asia. A case study of the 528 Ferghana Valley in Uzbekistan. Ph.D. Dissertation, 529 Lund studies in sociology of law, Lund University, 530 Lund 531

Urinboyev R (2013b) Public administration developments 532 in post-Soviet Central Asia. In: Vintar M, 533 Rosenbaum A, Jenei G, Drechsler W (eds) The past, 534 present and future of public administration in Central 535 and Eastern Europe. NISPAcee Press, Bratislava, 536 pp 296-303 
Urinboyev R (2014) Is there an islamic public administration legacy in post-Soviet Central Asia? An ethnographic study of everyday Mahalla life in rural Ferghana, Uzbekistan. Adm Cult 15(2):35-57

Urinboyev R (2015) Local government capacity in postSoviet Central Asia. Public Policy Adm
14(3):177-199. https://doi.org/10.5755/j01.ppaa.14.3. 544 13431

545

Urinboyev R (2018) Mahalla. In: Ledeneva A (ed) 546 The global encyclopaedia of informality. UCL Press, 547 London. Retrieved from http://in-formality.com/wiki/ 548 index.php?title $=$ Mahallah 


\section{Author Queries}

Global Encyclopedia of Public Administration, Public Policy, and Governance

Chapter No.: 3665-1

\begin{tabular}{|l|l|l|}
\hline Query Refs. & Details Required & Author's response \\
\hline AU1 & $\begin{array}{l}\text { Please be aware that your name and affiliation and if } \\
\text { applicable those of you co-author(s) will be published as } \\
\text { presented in this proof. If you want to make any } \\
\text { changes, please correct the details now. Note that } \\
\text { corrections after publication will no longer be possible. }\end{array}$ & \\
\hline
\end{tabular}

Note:

If you are using material from other works please make sure that you have obtained the necessary permission from the copyright holders and that references to the original publications are included. 